\title{
Winter growth of mussels Mytilus edulis as a possible counter to food depletion by oystercatchers Haematopus ostralegus
}

\author{
S. McGrorty* \\ Institute of Terrestrial Ecology, Furzebrook Research Station, Wareham, Dorset BH20 5AS, United Kingdom
}

\begin{abstract}
The growth of mussels in temperate waters is generally described as fast in summer and slow or absent in winter. Two experiments are described which investigated whether adult mussels Mytilus edulis in the Exe estuary, Devon, UK, grew over the winters of 1994-95 and 1995-96 and, if so, whether this process countered depletion by, and substantially increased the food available for, their principal predator, the oystercatcher Haematopus ostralegus. Mussels grew in length over both winters (September to March). In 1995-96, for example, there was a significant mean incremental growth for 25 to $45 \mathrm{~mm}$ mussels at $75 \%$ of sites. Overall, $71 \%$ of individually labelled mussels grew by $>1 \mathrm{~mm}$ and the largest individual increment was $9.6 \mathrm{~mm}$. Thus, some small mussels could have grown into the oystercatchers' preferred prey size range (lower limit ca $40 \mathrm{~mm}$ ) on all of the beds; but, given the rapid decline in growth with increasing length, it was unlikely that any grew out of it (upper limit ca $65 \mathrm{~mm}$ ). Growth varied between mussel beds but, contrary to expectation, there was no evidence that it varied with mussel clump density within beds. At the bed scale, variation in growth increment was not strongly related to sediment type (sand/mud; including sediment with and sediment without naturally accurring mussel populations), suggesting that the location of the bed within the estuary was important. Position along the exposure/submergence (upshore) gradient explained ( $p<0.0001$ ) the largest proportion $(44 \%)$ of the variance in growth increment for $<40 \mathrm{~mm}$ mussels. In contrast, the density of adult mussels on the beds explained $(p<0.0001)$ only an additional $1.2 \%$ of the variance after the effect of exposure and initial length had been taken into account. Increasing density across the range of values encountered on the mussel beds reduced the growth increment by $33 \%$, compared with a $99 \%$ reduction across the range of exposure values. Thus, the density-dependent effect on winter growth was small compared to the effect of bed location. Nonetheless, by reducing the density of the larger mussels, oystercatcher predation could have some effect on the growth of smaller ones. Certainly, growth could counter depletion to some extent on all of the beds. Even on those high-shore beds with $<10 \%$ increase in prey density due to the growth of small adult mussels, this could be important to the birds. On the 3 large, low-shore beds with the largest increases $(>20 \%)$ in prey due to growth, equivalent to $>90 \%$ of the estimated depletion, this must have had a substantial effect on the birds' food supply over the winter period.
\end{abstract}

KEY WORDS: Winter growth - Mussels - Oystercatchers

\section{INTRODUCTION}

The population of common mussel Mytilus edulis in the Exe estuary, Devon, UK, and its principal avian predator, the oystercatcher Haematopus ostralegus, have been studied since 1976 (Goss-Custard et al. 1980). On

·E-mail: s.mcgrorty@ite.ac.uk average, since that date, ca 65 ha of mussel beds has supported ca 1600 oystercatchers over the winter period, September to March. The mussel population is distributed across a number of beds, which vary in area and in their position along the environmental gradients within the estuary, the most important of these being exposure/submergence, which is an important determinant of the size and density of mussels present (McGrorty \& Goss-Custard 1991, McGrorty et al. 1993). 
Oystercatchers prefer adult mussels between 40 and $65 \mathrm{~mm}$ long, but will eat smaller ones when large ones are scarce or of poor quality (Durell \& Goss-Custard 1984, Cayford \& Goss-Custard 1990). At low water feeding oystercatchers distribute themselves across the mussel beds and, in general, feed in higher densities on beds where prey density is higher (Goss-Custard et al. 1992). Several studies have shown that oystercatchers can substantially deplete their prey population over a single winter (for example, by up to $40 \%$; Zwarts \& Drent 1981), especially in those areas where prey, and thus oystercatchers, are initially most numerous. But oystercatchers do not regulate the mussel population. This occurs before the mussels become adults, i.e. in their first winter, when predation, probably due mainly to shorecrabs Carcinus maenas, is strongly and positively density-dependent (McGrorty et al. 1990, MCGrorty \& Goss-Custard 1993). However, oystercatchers undoubtedly reduce the long-term population density of mussels in the Exe estuary, both directly by eating adults and indirectly by removing settlement space for larvae among their byssus threads (Goss-Custard et al. 19961. By thinning out the larger adults, and reduring competition for food, oystercatchers may also allow remaining mussels to grow larger than they would otherwise have grown.

This paper deals only with mussel growth during the winter. That this could be important for oystercatchers became apparent when food depletion was predicted from individuals-based feeding/distribution models (Goss-Custard et al. 1995a, b), and the predicted values were compared to direct measures of depletion on individual beds. Overwinter losses of adult mussels from the beds, as calculated from survey data (1976 to 1983), were much more variable than those estimated from the feeding model (Fig. 5.11 b in Goss-Custard et al. 1996). Greater-than-predicted losses on some beds indicated that other mortality agents were also operating. However, the finding that fewer mussels than predicted were lost on other beds suggested that gains of large adult mussels were regularly occurring. Further, in an oystercatcher exclusion caye experiment, a net loss of large adult mussels was shown to be densitydependent (Fig 5.11c in Goss-Custard et al. 1996), with up to 20 to $30 \%$ depletion in the densest sites. However, the least dense site gained $20 \%$ large adult mussels over the winter period. These gains can only be explained if either large adult mussels migrate and/or small adult mussels grow during the winter. There is other indirect evidence suggesting adult mussels might migrate (McGrorty \& Goss-Custard 1995), but as yet no satisfactory method has been devised to measure immigration and emigration rates in the Exe. The possibility that small mussels might grow into the oystercatchers' preferred size range of prey during the winter period, and compensate for some of those eaten, is investigated in this paper as one possible cause of the gain in large mussels recorded in many sites.

In temperate waters, mussel growth is seasonal (Seed 1976), being rapid in spring and summer and slow or absent in winter. This pattern has been recorded many times, but few authors have specifically commented on growth in winter. Dare (1976) reported that growth virtually ceased between December and February, while Bayne \& Widdows (1978) found that the 'scope for growth' was negative for 4 to 5 winter months. Craeymeersch et al. (1986) recorded $>90 \%$ of shell growth between April and September and very low, or even negative, growth rates from September to March or May, depending on to the initial size of the mussel. Likewise, Sukhotin \& Kulakowski (1992) reported a positive correlation between seasonal growth and temperature, with $7 \%$ of the annual growth occurring between November and April. However, low winter temperatures per se may not be the cause of poor, or no, growth. In west Sweden, Loo \& Rosenberg (1983) found that low temperatures $\left(<5^{\circ} \mathrm{C}\right)$ did not inhibit growth when they coincided with the spring phytoplankton bloom. It is possible therefore that, given sufficient food (Page \& Ricard 1990. Smaal \& van Stralen 1990, Frechette \& Grant 1991, Frechette et al. 1992, Muschenheim \& Newell 1992), mussels in the Exe estuary could grow in winter.

Within a particular location, mussel density (Newell 1990, Svane \& Ompi 1993) and exposure/submersion, or level on the beach (Rodhouse et al. 1984, Wanink \& Zwarts 1993, Faldborg et al. 1994), have been identified as important determinants of growth, being measures of intraspecific competition for food and space and the time available to feed, respectively. Other environmental variables have also been shown to influence growth, for example distance up-estuary (Essink \& Bos 1985), sediments (Wanink \& Zwarts 1993), commensals/parasites (Bierbaum \& Ferson 1986) and pollution (Widdows \& Johnson 1988, Lapota et al. 1993). Given the wide distribution of mussel beds within the Exe estuary, it is probable that the likelihood of there being winter growth, and its magnitude, would vary from bed to bed along environmental gradients.

Seed (1976) commented that growth in mussels was highly variable, not only between localities and sizes/ages of mussels, but also between individuals within populations, and even within the same patch or clump of mussels. This may imply a strong genetic influence on growth strategy (see, for example, Newkirk 1980, Rodhouse et al. 1986, Gentili \& Beaumont 1988, Zouros \& Mallet 1989, Beaumont et al. 1993 ) in addition to environmental controls. This wide variation in growth between individuals at one place 
could be important for oystercatchers. Even if, on average, mussel growth over the winter is very small, a proportion of faster-growing individuals might still grow sufficiently to enter the birds' food size range and replenish some of those eaten.

This paper reports the results of 2 mussel growth experiments conducted in the Exe estuary, the first over the winter of 1994-95 and the second over the winter of 1995-96. In both experiments, mussels were contained within cages to prevent their dispersal by waves and currents and to protect them from predators. The numbers of mussels dying in the cages gave an estimate of overwinter mortality due to factors other than predation.

The overall aims of the study were to determine whether mussels grew during the winter and, if so, whether growth could offset depletion of the oystercatchers' food supply on some or all of the mussel beds on which they fed. Because it was not logistically possible to measure growth on all of the beds, the strategy of locating study sites on a selection of beds along environmental and mussel density gradients was adopted, thus enabling functions to be derived and estimates of growth to be calculated for the remaining beds.

In the first experiment, 3 size groups of mussels ( 28 to 32,38 to 42 and 48 to $52 \mathrm{~mm}$ long, hereafter referred to as 30,40 and $50 \mathrm{~mm}$ mussels) were selected and growth determined by following changes in group mean lengths. The aims of this experiment were (1) to determine whether mussels in the Exe estuary grew over the 1994-95 winter period; and, if so (2) to compare mean growth increments at different local (cage) densities, (3) to determine if bed density had an effect by comparing growth increments of mussels on a large dense bed with that on bare sediment (i.e. bed density $=0 \mathrm{~m}^{-2}$ ) nearby, holding exposure level constant, and (4) to compare mean growth increments of mussels growing on different sediments.

In the second experiment, all of the mussels were individually labelled, thereby allowing the proportion of individuals growing into the oystercatchers food range to be assessed. Because the 1994-95 data indicated that local (cage) density and substrate had no effect on mean growth increment, all replicate cages in the 1995-96 winter experiment had the same num- ber of mussels and were placed on mussel beds. The 1994-95 results also indicated that the location of the bed, rather than the density of mussels on it, was the most important variable determining mean growth increment; thus, cages were placed on a selection of beds lying at different levels on the shore. The aims of the second experiment were to determine (1) whether mussels in the Exe estuary grew over the 1995-96 winter period; and, if so (2) whether growth varied between beds and which factors were responsible for the differences, (3) whether growth was densitydependant at the bed scale, so that oystercatchers by eating larger mussels allowed smaller ones to grow into the preferred food size category, and (4) whether growth could offset depletion arising from oystercatcher predation on some, or all, of the mussel beds in the estuary.

\section{STUDY AREA AND METHODS}

The River Exe in Devon, SW England, forms a small, mainly muddy, sheltered estuary protected from the sea by twin sand spits which reduce the entrance to a narrow channel. There are currently 10 main mussel beds scattered throughout the seaward half of the estuary. There is considerable variation among beds in the densities and sizes of mussels they support, in their exposure/submergence and in the range of substrata on which they occur, from gravel near the sea to very soft mud further up the estuary.

Winter is defined as the period from mid-September, when the oystercatcher population has almost reached its winter level, to mid-March, when most of the adult birds have left the estuary to breed elsewhere. The winter climate is generally mild, with the lowest air temperature of the study period $\left(-4.9^{\circ} \mathrm{C}\right)$ recorded in January 1996. The long-term (30 yr) monthly mean air temperatures in Exmouth, at the mouth of the estuary, vary from $14.8^{\circ} \mathrm{C}$ in September to $5.2^{\circ} \mathrm{C}$ in February (Table 1). The winter of 1994-95 was, on average, warmer $\left(9.7^{\circ} \mathrm{C}\right)$, than the winter of $1995-96\left(8.4^{\circ} \mathrm{C}\right)$, which was very close to the long-term average winter temperature $\left(8.5^{\circ} \mathrm{C}\right)$. Even so, only the November 1994 temperature was significantly higher $(\mathrm{p}<0.05)$ than the long-term mean temperature. Overall, neither

Table 1. Mean winter air temperatures at Exmouth, Devon, SW England

\begin{tabular}{|lccccccc|}
\hline Air temperature $\left({ }^{\circ} \mathrm{C}\right)$ & Sep & Oct & Nov & Dec & Jan & Feb \\
\hline Long-term $(30 \mathrm{yr}) \pm \mathrm{SD}$ & $14.8 \pm 1.0$ & $12.1 \pm 1.1$ & $8.6 \pm 1.2$ & $6.7 \pm 1.4$ & $5.5 \pm 1.8$ & $5.2 \pm 2.1$ & $6.7 \pm 1.3$ \\
$1994-95$ & 13.7 & 11.7 & 11.8 & 8.6 & 7.0 & 8.2 & 6.9 \\
$1995-96$ & 14.8 & 14.0 & 9.2 & 4.6 & 6.2 & 4.4 & 5.8 \\
\hline
\end{tabular}


winter was exceptionally warm or cold; temperature, therefore, was unlikely to have had a major influence on whether mussels grew or not.

Expt 1, winter 1994-95. Groups of four $20 \times 20 \times$ $20 \mathrm{~cm}, 13 \mathrm{~mm}$ mesh galvanised wire cages were placed $2 \mathrm{~m}$ apart at each study location or 'site'. The cages were held in place on the substrate by 4 canes $(1.5 \mathrm{~m}$ long) to which they were attached by synthetic twine. This system allowed flexibility to withstand tidal currents and fouling, while causing little, if any, additional scour or deposition of sediment. Sites were established in 3 'areas' of the estuary, each area being centered on a large mussel bed, such that 3 sites were located in the central parts of mussel Beds 20, 26 and 31 (see McGrorty et al. 1990 for a map of the mussel beds), 3 on bare sandflats adjacent to each of these mussel beds and 2 on bare mudflats adjacent to Beds 20 and 26. There was no mudflat near Bed 31. The study areas chosen were widely separated within the estuary (Bed 31 near the mouth, 26 mid-way and 20 at the up-estuary limit of mussels) and at different levels on the shore. In each area, the sites that were placed on and off the mussel bed were all positioned at the same exposure/submergence level. This on-bed and off-bed design was employed to test for a large, bed scale density effect and a sediment effect on mussel growth.

At each site, 30 mussels, 10 of each size group, were placed in each of 2 cages and 120 mussels, 40 of each size group, were placed in each of the other 2 cages to test for the effects of local density on growth. The lower density represented the usual pattern on the beds, i.e. a single layer of mussels within patches or small clumps. The higher density represented the highest observed patch densities, with mussels 2 to 3 layers deep. The lengths of all of the mussels in the cages were measured to the nearest $0.1 \mathrm{~mm}$ using vernier callipers in September, November, January and March and any mortalities noted.

It was not possible to measure all of the experimental mussels even over a single spring tide series because of weather and tidal conditions. It took a minimum of 1 wk to cut the byssus, measure all 2400 mussels in the 32 cages with the minimum of disturbance, and service the cages. The mean length of each size group $(30,40 \& 50 \mathrm{~mm})$ in each cage on, for example, the first (16 September 1994) and last (15 March 1995) days of winter were, therefore, estimated from regression analyses of length against the dates when measurements were actually made. These values were used to calculate mean overwinter growth increments.

Expt 2, winter 1995-96. Five cages, constructed and secured as in 1994-95, were placed in a line at $2 \mathrm{~m}$ intervals in the central part of 5 'flat' mussel beds (in order up-estuary Beds 27,26, 25, 22 and 20) which lie in a line up the eastern side of the estuary, but at different exposure/submergence levels $(40,36,28,17$ and $25 \%$ aerial exposure respectively). A further 3 sets of cages were placed at high- $(50 \%)$, mid- $(30 \%)$ and low- $(10 \%)$ exposure levels on Bed 30, a steeply sloping bed near the mouth of the estuary. Twenty mussels collected haphazardly at each site, and ranging from 25 to $45 \mathrm{~mm}$ long, were placed in each cage. The mussels were individually labelled, using numbered self-adhesive coloured plastic tapes from a Brother P-touch 2000 system and cyanoacrylic 'superglue' applied to the shell for extra security. All the cages were set up by the end of August and the mussels measured to $0.1 \mathrm{~mm}$ using vernier callipers in September, November, January and March. On each occasion, mortalities were noted and any lost labels replaced. This arrangement allowed the growth of individual mussels to be measured and any differences within and between sites to be detected.

Together the 8 sites covered the full range of conditions in which mussels occur in the Exe estuary: from 10 to $50 \%$ aerial exposure, 0.78 to $3.01 \mathrm{~km}$ up-estuary from the mouth, gravel to muddy sediments (measured as substrate softness, 0.38 to $17.4 \mathrm{~cm}$ penetration by a standard rod dropped from a height of $1 \mathrm{~m}$; McGrorty \& Goss-Custard 1991), bed areas from 1.11 to 9.49 ha and adult mussel densities of 143 to $896 \mathrm{~m}^{-2}$. The percentage aerial exposure at each site was measured by recording the times of exposure and submergence of the cages over a range of spring and neap tides. Bed areas and mussel densities were estimated from a survey of the whole intertidal population made in September 1995. Five hundred samples 10.04 or $0.02 \mathrm{~m}^{2}$ in area) were collected from the 10 mussel beds using a stratified random sampling scheme (McGrorty et al. 1990). Sample quadrat size varied according to mussel density and the number of samples in each stratum varied according to bed area.

To check the accuracy of mussel length measurements in the field, 100 mussels haphazardly selected in the muddiest part of Bed 26 were measured twice, at the beginning and end of the low-water period. This was carried out on a cold, wet, windy and overcast day in October, which represented the worst measuring conditions experienced during the study. Of the paired values, $90 \%$ were within $\pm 0.2 \mathrm{~mm}$, but the remainder varied by up to $\pm 0.5 \mathrm{~mm}$.

\section{RESULTS}

\section{Expt 1, winter 1994-95}

\section{Overwinter trends in mussel length}

Of the 96 regression analyses ( 3 size categories $\times 32$ cages) of mussel length against time, 92 had positive 
Table 2. Mytilus edulis. Overwinter trends in mussel length summary of regression analyses of length in mm against number of days elapsed since 15 September 1994 for 32 cages The slope, $b$, of the regression is the growth rate in $\mathrm{mm} \mathrm{d}^{-1}$, $p<0.05$ indicates the number of cases in which the relationship was significant at the $5 \%$ level of probability

\begin{tabular}{|lccccc|}
\hline $\begin{array}{l}\text { Length } \\
\text { class }\end{array}$ & $\begin{array}{c}\text { Mean } \\
\text { slope, } b \\
\left(\mathrm{~mm} \mathrm{~d}^{-1}\right)\end{array}$ & $\begin{array}{c}\text { Min. } \\
\text { (n) }\end{array}$ & $\begin{array}{c}\text { Max. } \\
b\end{array}$ & $\mathrm{p}<0.05$ & $\begin{array}{c}\text { Mean } \\
\text { growth } \\
\text { increment } \\
\text { (mm) }\end{array}$ \\
\hline $30 \mathrm{~mm}$ & 0.0112 & 0.0021 & 0.0215 & 22 & 2.02 \\
$40 \mathrm{~mm}$ & 0.0059 & -0.0014 & 0.0143 & 10 & 1.05 \\
$50 \mathrm{~mm}$ & 0.0029 & -0.0019 & 0.0120 & 1 & 0.51 \\
\hline
\end{tabular}

slopes ( $b=$ growth rate in $\mathrm{mm} \mathrm{d}^{-1}$ ) indicating overwinter growth had occurred. However, the growth rate was significantly greater than zero ( $t$-test, $p<0.05$ ) in only 33 cases. The majority of these significant relationships (22 cases) were for the smallest mussels $(30 \mathrm{~mm}$; Table 2). The number of cages in which there was significant growth declined with increasing size of the mussels such that, for $50 \mathrm{~mm}$ mussels, there was only a single significant relationship. The mean growth rate across all cages approximately halved with each $1 \mathrm{~cm}$ increase in initial mussel length, so that the mean growth increment for the winter period varied between $2.0 \mathrm{~mm}$ for $30 \mathrm{~mm}$ mussels and $0.5 \mathrm{~mm}$ for $50 \mathrm{~mm}$ mussels. Given these results, it is extremely unlikely that any larger mussels grew out of the size class eaten by oystercatchers (upper limit $65 \mathrm{~mm}$ ), but clearly some smaller mussels could have grown through the $40 \mathrm{~mm}$ lower limit of the birds' preferred class of prey.

\section{Variation in overwinter growth of mussels}

The influence of the 4 variables, study 'area', 'substrate', clump 'density' and mussel 'length', on overwinter growth was investigated by analysing the variance in growth increment between 16 September 1994 and 15 March 1995, using cages as replicates. Unfortunately, the absence of a muddy site near Bed 31 prevented a 4 -way multiple analysis of variance (ANOVA) from being performed. This would have identified those variables having a significant effect on growth and also any interactions between them. Instead, a multiple regression analysis was then used to test for their effects in the presence of each other (Table 3). A 3-way ANOVA was then performed (Table 4) using the 8 sites, which allowed some of the interactions between variables to be examined.

The multiple regression analysis indicated that mussel length and study area had a significant effect ( $p<$
0.0001; Table 3) on growth increment, whereas substrate and local cage/clump density did not. Between them, mussel length and study area explained $54 \%$ of the variance in overwinter growth increment. Mean growth increments across all areas and substrates decreased with increasing length of the mussels (30 mm: $2.02 \pm 0.14 \mathrm{~mm} ; 40 \mathrm{~mm}: 1.05 \pm 0.11 \mathrm{~mm}$; $50 \mathrm{~mm}: 0.51 \pm 0.08 \mathrm{~mm}$ ). The mean growth increment across all lengths and substrates was greatest in the study area centered on Bed 31 and least in the area of Bed 26 (mean growth in Bed 31 area: $1.83 \pm 0.22 \mathrm{~mm}$, Bed 20 area: $1.12 \pm 0.11 \mathrm{~mm}$, Bed 26 area: $0.85 \pm$ $0.13 \mathrm{~mm}$ ) The results therefore suggest that there was a difference in growth between study areas, but that the difference was not related to differences in the density of mussels or in the sediments (including sediment with and sediment without naturally occurring mussel populations). Thus, the difference must be related to the location of the areas within the estuary, and most probably to the length of the exposure/submergence period. This could not be tested effectively with only 3 areas, but growth was greater in the areas centered on Beds 31 and 20, sited just above the lowwater mark of spring tides, than in the area of Bed 26 , which lay above the low-water mark of neap tides.

Table 3. Multiple regression analysis of overwinter (1994-95) growth increment of mussels on 4 explanatory variables. ns: not significant at the $5 \%$ level of probability. $R^{2}=54 \%$

\begin{tabular}{|lclrc|}
\hline Predictor & $\begin{array}{c}\text { Partial } \\
\text { regression } \\
\text { coefficient }\end{array}$ & SD & $t$-ratio & $\mathrm{p}$ \\
\hline Constant & 2.749 & 0.539 & 5.10 & 0.0001 \\
Length & -0.076 & 0.008 & -9.93 & 0.0001 \\
Study area & 0.054 & 0.015 & 3.70 & 0.0001 \\
Substrate & 0.080 & 0.082 & 0.98 & $0.328 \mathrm{~ns}$ \\
Density & -0.00057 & 0.0014 & -0.41 & $0.680 \mathrm{~ns}$ \\
\hline
\end{tabular}

Table 4. General linear model: 3-way ANOVA on overwinter (1994-95) growth increment of mussels. (Study area and Substrate from Table 3 are replaced by the 8 Sites)

\begin{tabular}{|lrrrl|}
\hline $\begin{array}{l}\text { Source of } \\
\text { variance }\end{array}$ & df & SS & $F$ & $p$ \\
\hline Length & 2 & 37.51 & 145.03 & 0.0001 \\
Site & 7 & 22.53 & 24.89 & 0.0001 \\
Density & 1 & 0.06 & 0.49 & $0.487 \mathrm{~ns}$ \\
Length $\times$ Site & 14 & 4.27 & 2.36 & 0.014 \\
Length $\times$ Density & 2 & 0.37 & 1.44 & $0.246 \mathrm{~ns}$ \\
Site $\times$ Density & 7 & 2.09 & 2.31 & 0.041 \\
Length $\times$ Site & 14 & 2.34 & 1.29 & $0.248 \mathrm{~ns}$ \\
$\quad \times$ Density & & & & \\
\hline
\end{tabular}


The 3-way ANOVA using site as a variable (Table 4) allowed some of the interactions between variables to be examined. It confirmed that mussel length and site had a significant overall effect on growth increment, but local density did not. However, there was a significant interaction between site and density, indicating that, despite the general pattern of there being no difference, at some sites growth did vary with density. The best example of this was at the sandflat site close to Bed 26 where the mean growth in the low-density cages was clearly less than in the high-density cages (30 mm mussels: low density 1.68 and $1.74 \mathrm{~mm}$, high density 2.21 and $2.28 \mathrm{~mm} ; 40 \mathrm{~mm}$ mussels: low density 0.40 and $0.33 \mathrm{~mm}$, high density 1.12 and $1.27 \mathrm{~mm}$ ). Observations suggested that this might have been due to 'sand blasting'; the shells of most of the low density mussels were eroded over the winter, whereas in the high density cages most were not affected. There was also a significant interaction between site and length, indicating that at some sites, despite the general trend for smaller mussels to grow more than larger ones, large mussels grew more than smaller ones. Again the clearest example was at the sandflat site, close to Bed 20, where in 2 of the cages $40 \mathrm{~mm}$ mussels had a larger mean increment than the $30 \mathrm{~mm}$ mussels ( 1.47 vs $1.23 \mathrm{~mm}$ and 1.95 vs $1.85 \mathrm{~mm}$ ), though the differences were small and in the other 2 cages the normal pattern prevailed. There was no obvious explanation for these differences

Clearly, many mussels grew during the 1994-95 winter in the 3 mussel bed areas selected for the experiment. This was particularly true for the smallest mussels, but there was little evidence of growth among the largest. It is possible, therefore, that small mussels could grow into the oystercatchers' preferred prey size class, but most unlikely that large mussels would grow out of it during the winter. The analyses indicate that of the 4 variables tested only mussel length and study area had a significant effect on mean growth increment. However, the significance of the study area was clearly not related to the substrate or the local (within bed) clump density of mussels, suggesting that location within the estuary must influence mussel growth.

\section{Mortality}

The mussels in the cages were protected from oystercatcher predation, but some still died of other unknown causes. The proportion dying ranged from 0 to $23 \%$ in individual cages, but analyses failed to reveal any discernible pattern in relation to bed, substrate, mussel density or mussel length. Overall, $5.8 \%$ of the adult mussels in the cages died during the 1994 95 winter period.
Expt 2, winter 1995-96

Overwinter changes in mean length

Regression analyses of length against time for each of the 8 sites gave growth rates (positive coefficients) varying between $0.0035 \mathrm{~mm} \mathrm{~d}^{-1}$ and $0.0229 \mathrm{~mm} \mathrm{~d}^{-1}$ (Table 5), equivalent to overwinter growth increments of, on average, 0.6 to $4.2 \mathrm{~mm}$. However, at Sites 1 and 2 (see Table 5), the regression coefficients were not significantly greater than zero (at $\mathrm{p}<0.05$ ), indicating that on average, mussels at these 2 sites did not grow over the winter. At the other 6 sites, mussels did grow, but at different rates. This difference was confirmed by an ANOVA of overwinter growth increment (Table 6), which indicated that there were significant differences between sites, but not between cages within sites.

Table 5. Overwinter (1995-96) changes in mean mussel length with date. 30-1, 30-2 and 30-3 represent upper-, midand low-level sites on Bed 30 respectively. ns: not significant at $p<0.05$

\begin{tabular}{|lllllc|}
\hline Site Bed & $\begin{array}{c}\text { Regression } \\
\text { coefficient, } b, \\
\pm \text { SD }\end{array}$ & t-ratio & $p$ & $\begin{array}{c}\text { Mean } \\
\text { increment } \\
(\mathrm{mm})\end{array}$ \\
\hline 1 & $30-1$ & $0.0035 \pm 0.0043$ & 0.81 & $0.418 \mathrm{~ns}$ & 0.6 \\
2 & 27 & $0.0055 \pm 0.0042$ & 1.31 & $0.190 \mathrm{~ns}$ & 1.0 \\
3 & 26 & $0.0104 \pm 0.0037$ & 2.81 & 0.005 & 1.9 \\
4 & 25 & $0.0132 \pm 0.0033$ & 4.07 & 0.000 & 2.4 \\
5 & $30-2$ & $0.0181 \pm 0.0035$ & 5.11 & 0.000 & 3.3 \\
6 & 20 & $0.0193 \pm 0.0032$ & 6.03 & 0.000 & 3.5 \\
7 & $30-3$ & $0.0214 \pm 0.0038$ & 5.61 & 0.000 & 3.9 \\
8 & 22 & $0.0229 \pm 0.0033$ & 7.05 & 0.000 & 4.2 \\
\hline
\end{tabular}

Table 6. General linear model: 2-way ANOVA on overwinter (1995-96) growth increment of mussels

\begin{tabular}{|lrrrr|}
\hline Source & df & \multicolumn{1}{c}{ SS } & \multicolumn{1}{c}{$F$} & \multicolumn{1}{c|}{$p$} \\
\hline Site & 7 & 1.263 .54 & 75.91 & 0.000 \\
Cage & 4 & 9.09 & 0.96 & 0.431 \\
Error & 732 & 1740.66 & & \\
Total & 743 & & & \\
\hline
\end{tabular}

\section{Growth of individual mussels}

While there was no overall trend in mean length over the winter on 2 mussel beds, it was evident from the individually labelled mussels (Fig. 1a, c) that even on these beds some had grown. Table 7 shows the percentage of individuals at each site that had increased in length by $>1 \mathrm{~mm}$, equivalent to twice the maximum measurement error of $0.5 \mathrm{~mm}$. Using this criterion of 

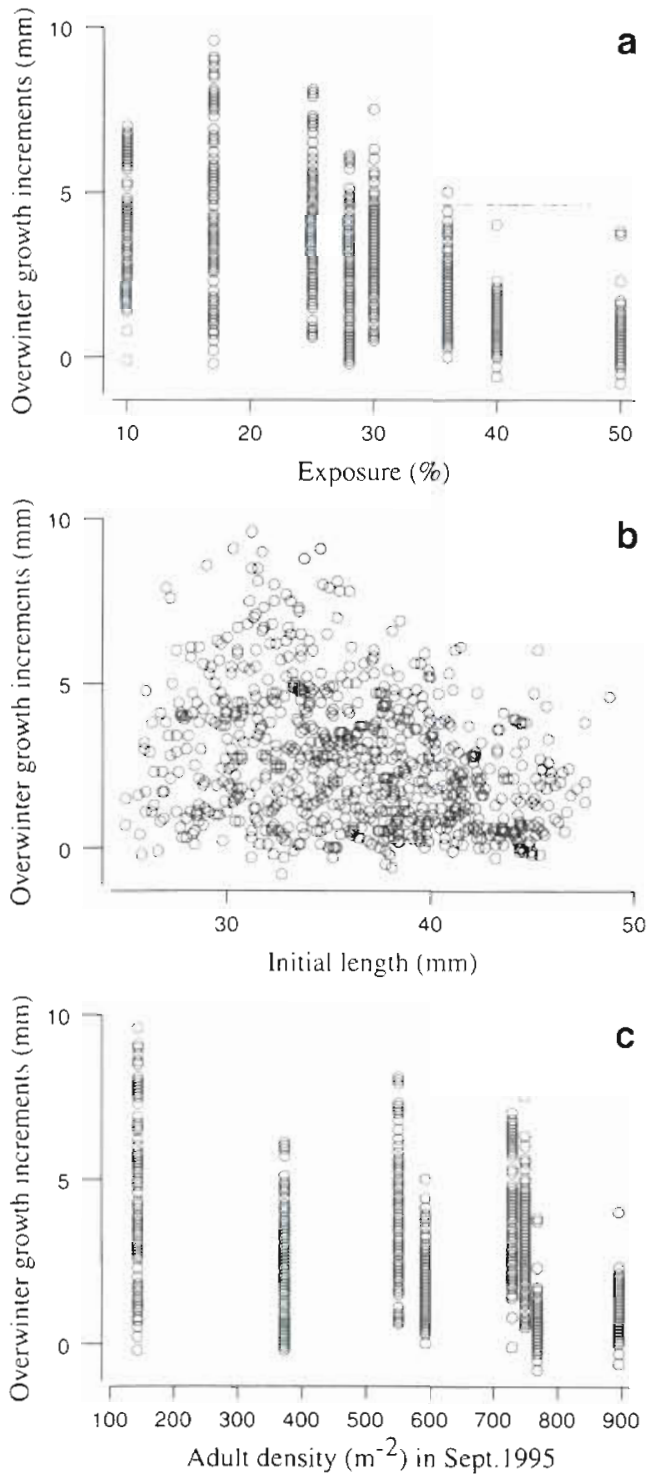

Fig. 1. Mytilus edulis. Overwinter growth increments of all labelled mussels that survived from September 1995 to March 1996 plotted against 3 well-known determinants of mussel growth, (a) aerial exposure (/submergence), (b) mussel length (/age) and (c) mussel density. These graphs illustrate the wide variation in growth of individual mussels even at those sites (beds), or for those initial lengths, at which growth was generally poor

growth, $13 \%$ of individual mussels at Site 1 grew over winter and $43 \%$ grew at Site 2 . On the other 6 beds, between 76 and $91 \%$ of individuals grew by $>1 \mathrm{~mm}$. Table 7 also shows the percentage of individuals that grew during early-, mid-and late- winter periods. On average, over all 8 sites, over half of the mussels (54\%) grew during the early winter (September to November), but very few (4\%) grew during late winter (January to March). Although growth varied from site to site, some mussels could have grown into the oystercatcher
Table 7 Mytilus edulis. Percentage of individually labelled mussels (100 mussels per site) growing by $>1 \mathrm{~mm}$ during winter (1995-96) periods

\begin{tabular}{|lcccc|}
\hline Site & Sep-Nov & Nov-Jan & Jan-Mar & Sep-Mar \\
\hline 1 & 0 & 6 & 3 & 13 \\
2 & 8 & 5 & 1 & 43 \\
3 & 49 & 29 & 2 & 83 \\
4 & 61 & 30 & 1 & 76 \\
5 & 67 & 44 & 9 & 90 \\
6 & 80 & 62 & 6 & 89 \\
7 & 81. & 24 & 2 & 84 \\
8 & 84 & 35 & 7 & 91 \\
Mean & 54 & 29 & 4 & 71 \\
\hline
\end{tabular}

food range at all of the sites to replace some of those eaten. However, the likelihood of this happening declined through the winter

\section{Variation in growth between sites}

The possible effect of 6 explanatory variables on overwinter (September to March) growth was first tested separately by simple regression analyses, using the growth increments of all 800 labelled mussels, and then together by a stepwise multiple regression procedure. The variables were: initial length of the mussel; bed-wide mean densities of small (25 to $39 \mathrm{~mm}$ ) mussels; bed-wide mean densities of large (40 to $65 \mathrm{~mm}$ ) mussels; percentage aerial exposure, equivalent to level on the shore; distance up the estuary from the sea; and substrate softness, a measure of muddiness. The logarithmic transformation of the 2 estimates of density were used to stabilise the variance. The square of exposure was used as the relationship with growth increment was curvilinear.

Overwinter growth increment was significantly ( $p<$ 0.001 ) related to all 6 variables (Table 8 ). The regression coefficients for initial length, the 2 mussel densities and exposure were negative, while those for distance up the estuary and substrate softness were positive. Thus, growth increments were largest in small adult mussels, on low density, low level, muddy beds up the estuary away from the sea. Although growth increment increased down the beach with decreasing percentage exposure, the maximum mean increment was not at the lowest site (Site 7, Bed 30-3) at $10 \%$ exposure, but at Site $8($ Bed 22 ) at $17 \%$ exposure; hence the squared relationship.

Exposure was the most important variable, explaining, on its own, $36 \%$ of the variance in growth increment. In comparison, the remaining variables explained on their own rather little of the variance ( 1.5 to $10.2 \%$ ). When the effects of the explanatory variables 
Table 8. Mytilus edulis. Simple regression analyses of overwinter (September 1995 to March 1996) growth increment of mussels $(\mathrm{mm})$ on 6 explanatory variables separately

\begin{tabular}{|c|c|c|c|c|c|}
\hline Variable & Constant & $\begin{array}{c}\text { Regression } \\
\text { coefficient }\end{array}$ & t-ratio & $\mathrm{p}$ & $r^{2}(\%)$ \\
\hline Initial length (mm) & 6.505 & -0.105 & -7.84 & 0.000 & 7.6 \\
\hline Log density $25-39 \mathrm{~mm}\left(\mathrm{~m}^{-2}\right)$ & 6.985 & -1.918 & -9.20 & 0.000 & 10.2 \\
\hline Log density $40-65 \mathrm{~mm}\left(\mathrm{~m}^{-2}\right)$ & 8.616 & -2.604 & -7.88 & 0.000 & 7.7 \\
\hline Exposure $^{2}(\%)$ & 4.391 & -0.00172 & -20.59 & 0.000 & 36.4 \\
\hline Distance up-estuary (km) & 1.754 & +0.521 & 6.34 & 0.000 & 5.1 \\
\hline Substrate softness $(\mathrm{cm})$ & 2.201 & +0.0421 & 3.36 & 0.001 & 1.5 \\
\hline
\end{tabular}

Table 9. Mytilus edulis. Stepwise multiple regression analysis of overwinter (1995-96) growth increment (mm) of adult (25 to $50 \mathrm{~mm}$ ) mussels on 5 explanatory variables. Values are partial regression coefficients. $N=744, F$-to-enter or remove $=4.0 ; p<$ 0.0001 for all variables selected

\begin{tabular}{|c|c|c|c|c|c|}
\hline Step: & 1 & 2 & 3 & 4 & 5 \\
\hline Constant & 4.391 & 8.760 & 10.097 & 12.253 & 12.211 \\
\hline $\begin{array}{l}\text { Exposure }^{2}(\%) \\
t \text {-ratio }\end{array}$ & $\begin{array}{l}-0.00172 \\
-20.59\end{array}$ & $\begin{array}{l}-0.00177 \\
-23.00\end{array}$ & $\begin{array}{l}-0.00170 \\
-20.79\end{array}$ & $\begin{array}{l}-0.00170 \\
-20.85\end{array}$ & $\begin{array}{l}-0.00152 \\
-18.81\end{array}$ \\
\hline $\begin{array}{l}\text { Initial length }(\mathrm{mm}) \\
t \text {-ratio }\end{array}$ & & $\begin{array}{l}-0.119 \\
-11.58\end{array}$ & $\begin{array}{l}-0.118 \\
-11.55\end{array}$ & $\begin{array}{l}-0.120 \\
-11.78\end{array}$ & $\begin{array}{l}-0.128 \\
-13.08\end{array}$ \\
\hline $\begin{array}{l}\log \text { density } 40-65 \mathrm{~mm}\left(\mathrm{~m}^{-2}\right) \\
t \text {-ratio }\end{array}$ & & & $\begin{array}{l}-0.630 \\
-2.33\end{array}$ & $\begin{array}{l}-1.350 \\
-3.87\end{array}$ & $\begin{array}{l}-1.400 \\
-4.22\end{array}$ \\
\hline $\begin{array}{l}\text { Substrate softness }(\mathrm{cm}) \\
t \text {-ratio }\end{array}$ & & & & $\begin{array}{l}-0.040 \\
-3.23\end{array}$ & $\begin{array}{l}-0.261 \\
-9.12\end{array}$ \\
\hline $\begin{array}{l}\text { Distance up-estuary (km) } \\
\text { t-ratio }\end{array}$ & & & & & $\begin{array}{l}1.590 \\
8.48\end{array}$ \\
\hline $\mathrm{R}^{2}(\%)$ & 36.4 & 46.1 & 46.5 & 47.3 & 51.94 \\
\hline
\end{tabular}

were tested in the presence of each other in a stepwise multiple regression, these 4 variables explained only a further $15.5 \%$ of the variance after the effect of exposure had been taken into account (Step 1, Table 9). Of this, initial length (Step 2) explained $9.7 \%$ and the density of large adults, eaten by oystercatchers (Step 3), only a further $0.4 \%$. In the presence of the other variables, the relationship with substrate softness changed sign and became negative. In other words, although in general mussels grew best on the muddiest beds, it was not muddiness per se that was responsible. After the effects of exposure, initial length and adult density had been taken into account, growth increments were actually largest on the firmest, and so least muddy mussel beds. Only the density of small adult mussels was not chosen in the stepwise procedure, but this was not surprising since it was so highly correlated $(\mathrm{r}=0.88$ ) with the density of large adults.

Thus, the 1995-96 experiment confirmed the 1994-95 finding that mussels grew over winter in the Exe estuary, but there was a significant increase in mean length at only 6 of the 8 sites. However, even at those sites, where there was no overall trend in mean length, some individuals did grow. Some small mussels could, therefore, have grown into the oystercatchers' pre- ferred prey size range at all sites to replace some of those eaten. Growth increments varied between sites and the most important explanatory variable was exposure time, with growth increasing downshore. Other variables tested explained rather little of the variation in growth increment, either separately, or in the presence of each other. After the effect of exposure was taken into account, initial length of the mussel was the next most important variable, with small mussels growing more than large ones. The density of large mussels, i.e. those in the size range eaten by oystercatchers, explained $<1 \%$ of the residual variance; thus, any positive density-dependent effect on the growth of small mussels resulting from the depletion of large mussels by the birds is also likely to be small compared to the effect of exposure.

Numbers of mussels growing into the size range taken by oystercatchers over the winter

This multiple regression analysis (Table 9. Step 5) provided a predictive equation which could be used to estimate the mean growth increment for those beds not used in the experiment, and hence the numbers of 
Table 10. Mytilus edulis. Proportions and numbers of smaller size classes of mussels growing over the winter of $1995-96$ into the 40 to $65 \mathrm{~mm}$ class eaten by oystercatchers. Note that Beds 1, 3, 4 and 31 were not used in Expt 2, so values were calculated from the equation relating proportion to exposure. Values for Bed 30 are means of $30-1,30-2$ and $30-3$

\begin{tabular}{|c|c|c|c|c|c|c|c|}
\hline \multirow[t]{2}{*}{ Bed } & \multicolumn{2}{|c|}{$\begin{array}{l}\text { Proportion growing } \\
\text { into } 40+\text { mm class from: }\end{array}$} & \multicolumn{3}{|c|}{$\begin{array}{c}\text { Densities from September } 1995 \\
\text { survey }\left(\mathrm{m}^{-2}\right)\end{array}$} & \multirow{2}{*}{$\begin{array}{c}\text { No. }\left(\mathrm{m}^{-2}\right) \\
\text { growing into } \\
40.0-64.9 \mathrm{~mm}\end{array}$} & \multirow{2}{*}{$\begin{array}{l}\% \text { increase } \\
\text { in initial } \\
\text { September } \\
\text { density }\end{array}$} \\
\hline & $30.0-34.9 \mathrm{~mm}$ & $35.0-39.9 \mathrm{~mm}$ & $30.0-34.9 \mathrm{~mm}$ & $35.0-39.9 \mathrm{~mm}$ & $40.0-64.9 \mathrm{~mm}$ & & \\
\hline 1 & 0 & 0.133 & & 66.7 & 114.7 & 8.9 & 8 \\
\hline 3 & 0 & 0.465 & & 6.0 & 53.5 & 2.8 & 5 \\
\hline 4 & 0 & 0.531 & & 31.3 & 196.8 & 16.6 & 8 \\
\hline 20 & 0.143 & 0.909 & 47.4 & 52.3 & 220.7 & 54.3 & 25 \\
\hline 22 & 0.313 & 0.700 & 10.2 & 9.4 & 57.0 & 9.8 & 17 \\
\hline 25 & 0 & 0.469 & & 22.9 & 183.9 & 10.7 & 6 \\
\hline 26 & 0 & 0.407 & & 52.4 & 184.4 & 21.3 & 12 \\
\hline 27 & 0 & 0.069 & & 106.3 & 193.8 & 7.3 & 4 \\
\hline 30 & 0.010 & 0.426 & 119.9 & 141.3 & 278.2 & 61.4 & 22 \\
\hline 31 & 0 & 0.475 & & 56.6 & 113.4 & 26.9 & 24 \\
\hline
\end{tabular}

mussels in September 1995 that would have grown into the oystercatchers' range over the winter on all of the beds in the estuary. However, the equation explained only a little over half of the variance in growth, and another method was used which explained a greater proportion of the variance. The proportion of mussels in the 30 to $34 \mathrm{~mm}$ and 35 to $39 \mathrm{~mm}$ categories, which grew to $>40 \mathrm{~mm}$ over the winter, were estimated directly from the basic data (Table 10). These proportions were regressed against exposure, the bed mean densities of small ( 30 to $40 \mathrm{~mm}$ ) and large ( 40 to $65 \mathrm{~mm}$ ) adult mussels in September 1995 , the distance of the bed up the estuary and the substrate softness or muddiness. Only the square of exposure had a significant effect ( $p=0.009)$, on its own, or in combination with the other variables, and explained $70.6 \%$ of the variation in the proportion of 35 to $40 \mathrm{~mm}$ mussels growing into the oystercatchers' food range overwinter This gave the equation:

Proportion of mussels growing $=0.8096( \pm 0.1072, \mathrm{SD})$

$$
-0.000327( \pm 0.000086, S D) \text { Exposure }{ }^{2}
$$

which was used to calculate the proportion of small mussels that grew over the winter into the size-range eaten by oystercatchers for those beds not included in the experiment. Table 10 lists these proportions, mean bed densities $\left(\mathrm{m}^{-2}\right)$ from the September 1995 survey, and the numbers of mussels $\left(\mathrm{m}^{-2}\right)$ growing into the oystercatchers' food range on each of the 10 beds in the Exe estuary. These numbers varied from 2.8 to $61.4 \mathrm{~m}^{-2}$ and represent an overwinter increase in food supply for the birds of 4 to $25 \%$. Clearly, September surveys of adult mussels underestimate the potential winter food supply for oystercatchers, especially on Beds 20, 30 and 31 , where over $25 \mathrm{~m}^{-2}$ grow into prey range, replacing those already eaten and where, on average, $41 \%$ of the oystercatchers fed over the winter between 1976 and 1983.

\section{Mortality}

As in the previous winter, the 1995-96 experimental mussels were protected from predation by the wire cages, but some still died of unknown causes. Within cages the mortality ranged from 0 to $25 \%$ and within sites from 3 to $17 \%$. However, there was no detectable pattern to the mortality, either between bed5/sites or during the winter. Overall, $7 \%$ of the mussels (25 to $45 \mathrm{~mm}$ ) died over winter.

\section{DISCUSSION}

There is a large body of literature on the growth of mussels (see 'Introduction'), at least in part because of their importance to the shellfishing industry. However, few authors have specifically commented on the winter period, when in temperate waters growth is generally slow, or absent, compared to spring and summer. Nor, to our knowledge, has the possibility that the depletion of their prey by migratory shorebirds could be offset by the growth of small individuals into the preferred size range during the winter been considered previously.

It has been estimated that oystercatchers in the Exe estuary eat approximately $25 \%$ of their preferred prey over the winter period (J. D. Goss-Custard pers. comm.) and this study has shown that a further 5 to $7 \%$ die of other unknown causes. This implies that up to 
$70 \%$ of their prey remain at the end of winter. Why then should the addition of extra prey during the winter, either by growth or immigration, be of any importance to the birds, when there is apparently a large surplus?

One reason is that surveys of mussel beds only provide estimates of 'potential' prey $(40$ to $65 \mathrm{~mm}$ ) density and may considerably overestimate the actual prey available to oystercatchers. This is because mussels are difficult to open and, in doing so, birds risk breaking their bills, and perhaps consequently starving to death (Hulscher 1996). Individual oystercatchers either stab between the valves of mussels or hammer the shell until it breaks. 'Stabbers' attack submerged mussels which are agape or exposed mussels which are wet and, therefore, only lightly closed. 'Hammerers' choose those mussels with thin shells. Thus, both techniques involve selecting vulnerable mussels. The proportion of potential prey that are vulnerable to oystercatcher predation is unknown, but is likely to vary both spatially and temporally. If it is small, then oystercatchers may eat most of the vulnerable prey over the winter. If it is larqe, then there will be a surplus of prey remaining in spring. However, even in the latter case, prey may become increasingly difficult to locate among the matrix of unsuitable mussels as the winter progresses. In either case, the addition of extra prey during the winter could benefit the birds.

\section{Do mussels grow in winter?}

The first aim of these experiments was to determine whether adult mussels in the Exe estuary grew over the winter period, September to March. Many mussels, but not all, did grow over both winters. In 1994-95, there were significant increases in mean length, indicating that growth occurred in 69,31 and $3 \%$ of the 32 replicate cages for 30,40 and $50 \mathrm{~mm}$ mussels, respectively. In 1995-96, there were significant increases in 25 to $45 \mathrm{~mm}$ mussels at $75 \%$ of the sites; overall $71 \%$ of individuals grew by more than $1 \mathrm{~mm}$ and the largest individual growth increment was $9.6 \mathrm{~mm}$. Given the rapid decline in growth increment with increasing length, it is very unlikely that any mussels could have grown out of the oystercatchers' upper limit of $65 \mathrm{~mm}$. This is supported by unpublished data from an earlier trial of labelling and caging techniques on mussels up to $65 \mathrm{~mm}$ at Site 7 (Bed 30-3), the site with the second largest overwinter growth rate (Table 5). No mussels over $55 \mathrm{~mm}$ grew by more than the maximum measurement error of $0.5 \mathrm{~mm}$. However, small mussels could have grown into the size range $(40$ to $65 \mathrm{~mm}$ ) taken by oystercatchers on all of the beds.

\section{Are there bed differences in mussel growth rate?}

Given that winter growth occurred, the second aim of Expt 2 was to determine whether growth varied between mussel beds and, if so, to determine the factors responsible. There were clear differences in mean growth increments between study areas/sites in both winters, but this is best illustrated by the larger range of sites studied in 1995-96. Mean increments varied across the 8 sites from $0.6 \mathrm{~mm}$ (Bed 30-1, range 0 to $3.8 \mathrm{~mm}$ ) to $4.2 \mathrm{~mm}$ (Bed 22, range 0 to $9.6 \mathrm{~mm}$ ). Likewise, the percentage of individuals growing by more than $1 \mathrm{~mm}$ varied between sites from 13 to $91 \%$. The results indicated which factors were responsible for this variation in growth increment. The first experiment confirmed the expectation that small mussels would grow more than large ones. However, contrary to expectation, local density did not affect winter growth. There was a difference between study areas, but this did not appear to be strongly related to the substrate (including substrate with and without naturally occurring mussels).

This suggests that another aspect of location within the estuary was more important. This was confirmed by the results from the second experiment (and see Fig. 1) when aerial exposure (or level on the shore) and distance up the estuary from the sea were both found to be significant correlates of growth. Mussel length, the bed-wide density of large mussels and the softness (or muddiness) of the substrates had an additional, but much smaller effect. Together these variables explained $55 \%$ of the variance in overwinter growth increment for 25 to $39 \mathrm{~mm}$ mussels. However, exposure was by far the most important, explaining on its own $44 \%$ of the variation.

\section{Was growth density-dependent?}

On their own, the bed-wide densities of small (25 to $39 \mathrm{~mm}$ ) and large (40 to $65 \mathrm{~mm}$ ) adult mussels had a significant effect on growth, but in the presence of the other variables only the density of the larger mussels had a significant effect. But, after the effect of exposure and mussel length had been taken into account, density explained only an additional $1.2 \%$ of the variance. While this suggests that the effect of large adults on the growth increment of small adults is likely to be small, compared with, for example, the effect of exposure, the actual size of the effect is determined by the regression coefficient, and the range of values over which the variable has its effect, not by the $r^{2}$ value. To compare the actual effects of each explanatory variable on the mean growth increment, the maximum and minimum value of each variable measured at the 8 
sites were inserted in turn into the following multiple regression equation, while holding the other variables constant at their mean values. The equation was:

Mean growth increment $(25-39 \mathrm{~mm})=$ 12.918-0.00167 Exposure ${ }^{2}-0.113$ Initial length $-1.918 \log$ Adult $(40-65 \mathrm{~mm})$ density

-0.307 Substrate softness

+1.960 Distance up-estuary

The results of this analysis are presented in Table 11 , which shows, for each explanatory variable, (1) the range of values measured over the 8 sites, (2) the calculated range of mean growth increments, (3) the size of the effect of each variable, in terms of the percentage reduction in growth increment over its range, and (4) the direction, along each of these environmental gradients, in which growth declined. Clearly, small mussels grew more on beds with low densities, than on those with high densities of large adults. However, a 4.7 -fold increase in adult density resulted in only a $33 \%$ reduction in growth increment, compared to a $99 \%$ reduction in growth with a similar (5-fold) increase in percentage exposure time.

The third aim of Expt 2 was to determine whether growth was density-dependent at the bed scale. This was indeed the case. But, note that this was a bed-wide effect only; there was no significant effect of local, within-bed clump density on growth increment in the 1994-95 winter experiment. However, compared to the effect of aerial exposure, distance up-estuary or the softness of the substrate, the effect of oystercatchers eating large mussels, and thereby allowing smaller ones to grow into the food size range, was small.

\section{Does growth of mussels offset depletion?}

The final aim of the study was to assess whether overwinter growth of small mussels could offset the depletion of large mussels due to oystercatcher predation. To some extent this was the case on all of the beds in 1995-96. However, on half of them, the effect was small $\left(<10 \mathrm{~m}^{-2}\right.$ or $<10 \%$ increase; Table 10$)$, either because on high-level beds very few of them grew (e.g. Beds 30-1 and 27) or because bed-wide densities were low (e.g. Beds 3 and 22). Any increase could, of course, be important to the oystercatchers; even the minimum value of $2.8 \mathrm{~m}^{-2}(+5 \%)$, estimated for Bed 3 , implies a substantial addition of new mussels. How ever, on the other 5 beds with up to $25 \%$ increase (Bed $20,+54 \mathrm{~m}^{-2}$ ) and up to $61 \mathrm{~m}^{-2}$ (Bed $30,+22 \%$ ) mussels growing into the oystercatchers' range, growth must be considered to have had a substantial effect on overwinter food supply for the oystercatchers.

The potential of overwinter growth of small adult mussels to offset the depletion of large mussels by oystercatchers on each of the 10 beds during the 1995-96 winter is further illustrated in Fig. 2, which shows the average numbers of oystercatchers counted (by J. D. Goss-Custard) on the beds at low-water between September 1995 and February 1996. Beds are arranged in decending order of occupancy (Fig. 2a), and the numbers of large mussels ( 40 to $65 \mathrm{~mm}$ ) estimated by the survey in September 1995 are shown (Fig. 2b). While there is not an exact correspondence between bird numbers and mussel numbers, or mussel densities $\left(\mathrm{m}^{-2}\right.$; Table 10$)$, they were both significantly correlated $(r=0.63$ and $0.65, p<0.05)$. The number of mussels eaten by the birds is also indicated in Fig. $2 \mathrm{~b}$. This is based on an estimate of depletion (J. D. Goss-Custard pers. comm.) of $25 \%$ overall. Assuming that this figure applies equally to all of the beds, the percentage of the large mussels eaten replaced by small mussels growing into the oystercatchers' preferred prey size range is shown in Fig. 2c. Clearly, the 3 beds with the largest numbers of birds also have the highest percentage replacement of mussels eaten by the birds. By plotting the cumulative numbers of birds and percentage replacement of prey across the beds, it can be seen in Fig. 2d that these 3 beds $(31,20$ and 30$)$ accommodated $51 \%$ of the birds in the estuary and that on average $92 \%$ of the mussels eaten on these beds were replaced

Table 11. Mytilus edulis. Effects of 5 explanatory variables, chosen by multiple regression analysis (Table 9), on mean growth increment of small ( 25 to $39 \mathrm{~mm}$ ) mussels over the 1995-96 winter The mean growth increment is shown for the maximum and minimum values of each variable

\begin{tabular}{|lcccc|}
\hline Variable & $\begin{array}{c}\text { Range of } \\
\text { variable across } \\
\text { the } 8 \text { sites }\end{array}$ & $\begin{array}{c}\text { Calculated range } \\
\text { of growth } \\
\text { increment }(\mathrm{mm})\end{array}$ & $\begin{array}{c}\text { \% reduction in } \\
\text { mean growth } \\
\text { increment }\end{array}$ & $\begin{array}{c}\text { Direction of } \\
\text { reduction in } \\
\text { growth }\end{array}$ \\
\hline Exposure $(\%)$ & $10-50$ & $4.05-0.04$ & 99 & Upshore \\
Substrate softness $(\mathrm{cm})$ & $3.9-17.4$ & $4.63-0.49$ & 89 & Increasing muddiness \\
Distance up-estuary $(\mathrm{km})$ & $0.63-3.01$ & $0.77-5.43$ & 86 & Down-estuary \\
Initial length $(\mathrm{mm})$ & $25-39$ & $3.52-1.83$ & 33 & Small to large mussels \\
Large $(40-65 \mathrm{~mm})$ mussels $\left(\mathrm{m}^{-2}\right)$ & $58-275$ & $4.00-2.70$ & Low to high density \\
\hline
\end{tabular}



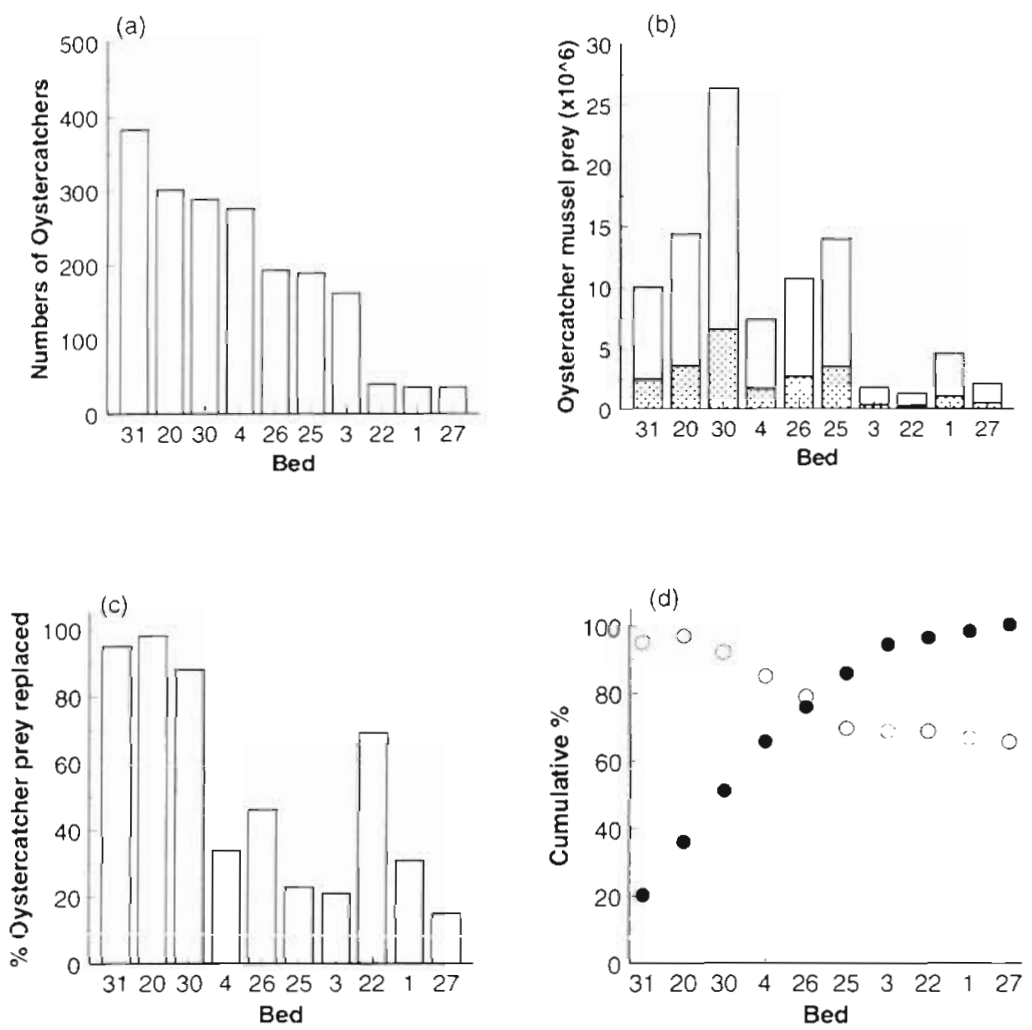

Fig. 2. Replacement of the preferred large (40 to $65 \mathrm{~mm}$ ) prey, eaten by oystercatchers during the 1995-96 winter, by small mussels growing into the size range. The graphs show (a) the mean numbers of oystercatchers counted during the winter months on the mussel beds, arranged in order of declining abundance, and (b) the numbers $\left(\times 10^{6}\right)$ of their preferred prey on the beds at the beginning of winter in September 1995. Shaded area represents the estimated overall proportion $(25 \%)$ of prey eaten by the oystercatchers, assuming that this applies equally to all beds. The proportion of these predated musseis that are replaced on each bed during the winter is shown in (c) and plotted with the number of oystercatchers in (d) as cumulative percentages. (d) Decline in the average proportion of musseis repiaced ioj across the veds as int proportion of the oystercatcher population feeding on them ( increases by smaller mussels which had grown during the winter. Likewise $76 \%$ of the birds occurred on 5 beds in which, on average, $79 \%$ of the mussels eaten were replaced, and over all the beds, on average, $65 \%$ of the mussels eaten by oystercatchers were replaced. Of course, these small mussels will contain less flesh than the larger ones, but especially in years when, or places where, large mussels are scarce, the growth of small mussels over the winter into the oystercatchers' preferred prey size range must be regarded as a potentially important process.

Acknowledgements. This work was carried out as part of a Commission of the European Communities DirectorateGeneral for Fisheries contract, PEM/93/03. I thank J. P. Lenton for help in setting up the second experiment, Dr J. D. Goss-Custard for providing the oystercatcher count data, Sandra Satterly for providing the weather data and Drs J. D. Goss-Custard and R. A. Stillman for constructive criticism of the manuscript

\section{LITERATURE CITED}

Bayne BL, Widdows J (1978) The physiological ecology of two populations of Mytilus edulis L. Oecologia (Berl) 37 : $137-162$

Beaumont AR, Abdul-Matin AKM, Seed R (1993) Early development, survival and growth in pure and hybrid larvae of Mytilus edulis and M. galloprovincialis. J Molluscan Stud 59:120-123
Bierbaum RM, Ferson S (1986) Do symbiotic pea crabs decrease growth rate in mussels? Biol Bull 170:51-61

Cayford JT, Goss-Custard JD (1990) Seasonal changes in the size selection of mussels, Mytilus edulis, by oystercatchers, Haematopus ostralegus: an optimality approach. Animal Behav 40:609-624

Craeymeersch JA, Herman PM, Meire PM (1986) Secondary production of an intertidal mussel (Mytilus edulis L.) population in the Eastern Scheldt (S.W. Netherlands). Hydrobiologia 133:107-115

Dare PJ (1976) Settlement, growth, and production of the mussel, Mytilus edulis L., in Morecambe Bay, England. Minist Agric Fish Food Fish Invest Ser II Mar Fish GB 28(1): $1-25$

Durell SEA, Goss-Custard JD (1984) Prey selection within a size-class of mussels, Mytilus edulis, by oystercatchers, Haematopus ostralegus. Animal Behav 32:1197-1203

Essink K, Bos AH (1985) Growth of three bivalve molluscs transplanted along the axis of the Ems estuary. Neth J Sea Res 19(1):45-51

Faldborg K, Jensen KT, Maagaard L (1994) Dynamics, growth, secondary production and elimination by waterfowl of an intertidal population of Mytilus edulis L. Ophelia (Suppl) 6:187-200

Frechette M, Aitken AE, Page L (1992) Interdependence of food and space limitation of a benthic suspension feeder: consequences for self-thinning relationships. Mar Ecol Prog Ser 83:55-62

Frechette M, Grant J (1991) An in situ estimation of the effect of wind-driven resuspension on the growth of the mussel Mytilus edulis L. J Exp Mar Biol Ecol 148:201-213

Gentili MR, Beaumont AR (1988) Environmental stress, heterozygosity, and growth rate in Mytilus edulis L. J Exp Mar Biol Ecol 120:145-153 
Goss-Custard JD, Caldow R, Clarke RT (1992) Correlates of the density of foraging oystercatchers Haematopus ostralegus at different population sizes. J Anim Ecol 61:159-173

Goss-Custard JD, Caldow RWG, Clarke RT, Durell SEA Sutherland WJ (1995a) Deriving population parameters from individual variations in foraging behaviour: I. Empirical game theory distribution model of oystercatchers Haematopus ostralegus feeding on mussels Mytilus edulis J Anim Ecol 64:265-276

Goss-Custard JD, Caldow RWG, Clarke RT, West AD (1995b) Deriving population parameters from individual variations in foraging behaviour: II. Model tests and population parameters. J Anim Ecol 64:277-289

Goss-Custard JD, McGrorty S, Durell SEA (1996) The effect of oystercatchers on shellfish populations. Ardea 84: 453-468

Goss-Custard JD, McGrorty S, Reading CJ, Durell SEA (1980) oystercatchers and mussels in the Exe estuary. In: Boalch GT (ed) Essays on the Exe estuary, Spec Vol 2. Devonshire Association, Devonshire Press, Torquay, p 161-185

Goss-Custard JD, West AD, Sutherland WJ (1996) Where to feed. In: Goss-Custard JD (ed) The oystercatcher, from individuals to populations. Oxford University Press, p $105-132$

Hulscher JB (1996) Food and feeding behaviour. In: GossCustard JD (ed) The oystercatcher, from individuals to populations. Oxford University Press, p 7-29

Lapota D, Rosenberger DE, Platter-Rieger MF, Seligman PF (1993) Growth and survival of Mytilus edulis larvae exposed to low levels of dibutyltin and tributyltin. Mar Biol 115:413-419

Loo LO, Rosenberg R (1983) Mytilus edulis culture, growth and production in western Sweden. Aquaculture 35:137-150

McGrorty S, Clarke RT, Reading CJ, Goss-Custard JD (1990) Population dynamics of the mussel Mytilus edulis: density changes and regulation of the population in the Exe estuary, Devon. Mar Ecol Prog Ser 67:157-169

McGrorty S, Goss-Custard JD (1991) Population dynamics of the mussel Mytilus edulis: spatial variations in age-class densities of an intertidal estuarine population along environmental gradients. Mar Ecol Prog Ser 73:191-202

McGrorty S, Goss-Custard JD (1993) Population dynamics of the mussel Mytilus edulis along environmental gradients: spatial variations in density-dependent mortalities. J Anim Ecol 62:415-427

McGrorty S, Goss-Custard JD (1995) Population dynamics of Mytilus edulis along environmental gradients: densitydependent changes in adult mussel numbers. Mar Ecol Prog Ser 129:197-213

McGrorty S, Goss-Custard JD, Clarke RT (1993) Mussel Mytilus edulis (Mytilacea) dynamics in relation to environ-

This article was submitted to the editor mental gradients and intraspecific interactions. Neth J Aquat Ecol 27(2-4):163-171

Muschenheim DK, Newell CR (1992) Utilisation of seston flux over a mussel bed. Mar Ecol Prog Ser 85:131-136

Newell CR (1990) The effects of mussel (Mytilus edulis, Linnaeus 1758 ) position in seeded bottom patches on growth at subtidal lease sites in Maine. J Shellfish Res 9: $113-118$

Newkirk GF (1980) Genetics of shell colour in Mytilus edulis $\mathrm{L}$. and the association of growth rate with shell colour J Exp Mar Biol Ecol 47:89-94

Page HM, Ricard YO (1990) Food availability as a limiting factor to mussel Mytilus edulis growth in California coastal waters. Fish Bull US 88:677-686

Rodhouse PG, McDonald JH, Newell RIE, Koehn RK (1986) Gamete production, somatic growth and multiple-locus enzyme heterozygosity in Mytilus edulis. Mar Biol 90: $209-214$

Rodhouse PG, Roden CM, Burnell GM, Hensey MP, McMahon T, Ottway B, Ryan TH (1984) Food resource, gametogenesis and growth of Mytilus edulis on the shore and in suspended culture: Killarney Harbour, Ireland. J Biol Assoc UK 64:513-529

Seed R (1976) Ecology. In: Bayne BL (ed) Marine mussels. International Biological Programme, Vol 10. Cambridge University Press, p 13-65

Smaal AC, van Stralen MR (1990) Average annual growth and condition of mussels as a function of food source. Hydrobiologia 195:179-188

Sukhotin AA, Kulakowski EE (1992) Growth and population dynamics in mussels (Mytilus edulis L.) cultured in the White Sea. Aquaculture 101:59-73

Svane I, Ompi M (1993) Patch dynamics in beds of the blue mussel Mytilus edulis L.: effects of site, patch size, and position within a patch. Ophelia 37(3):187-202

Wanink JH, Zwarts L (1993) Environmental effects on the growth rate of intertidal invertebrates and some implications for foraging waders. Neth J Sea Res 31(4):407-418

Widdows J, Johnson D (1988) Physiological energetics of Mytilus edulis: scope for growth. Mar Ecol Prog Ser 46: $113-121$

Zouros E, Mallet AL (1989) Genetic explanations of growth/ heterozygosity correlation in marine molluscs. In: Ryland JA, Tyler PA (eds) Reproduction, genetics and distributions of marine organisms. Olsen \& Olsen, Fredensborg. p $317-324$

Zwarts L, Drent RH (1981) Prey depletion and the regulation of predator density: oystercatchers (Haematopus ostralegus) feeding on mussels (Mytilus edulis). In: Jones NV, Wolff WJ (eds) Feeding and survival strategies of estuarine organisms. Plenum Press, New York, p 193-216

Manuscript first received: March 24, 1996

Revised version accepted: May 22, 1997 